Ethiopian Journal of Environmental Studies \& Management 10(5): 629 - 641, 2017.

ISSN:1998-0507

doi: https://dx.doi.org/10.4314/ejesm.v10i5.7

Submitted: March 19, 2017

Accepted: June 28, 2017

\title{
SPECIATION AND MOBILITY STUDY OF SELECTED HEAVY METALS IN KOFE DUMPSITE SOIL OF JIMMA TOWN, JIMMA, ETHIOPIA
}

\section{KASSIM KEDIR, *ABERA GURE AND YARED MERDASSA}

Jimma University, Collage of Natural Science, Department of Chemistry, Jimma, Ethiopia

\begin{abstract}
Speciation and mobility of selected heavy metals including $\mathrm{Cd}, \mathrm{Pb}$ and $\mathrm{Fe}$ were investigated in Kofe dumpsite soils of Jimma Town, Jimma, Ethiopia. To study vertical mobility of the metals, soil samples were collected at three depth profiles comprising surface soil $(0-10 \mathrm{~cm})$, subsoil $(20-30 \mathrm{~cm})$, and bottom soil $(40-50 \mathrm{~cm})$ using soil auger. Similarly, for horizontal mobility assessment, soil samples were collected from $5 \mathrm{~m}, 10 \mathrm{~m}$ and $15 \mathrm{~m}$ distances starting from the edge of the dumpsite in east, west, north and south directions. Control soil samples were also collected at the same depth profiles, from $200 \mathrm{~m}$ away from the dumpsite. The collected samples were air dried, sieved as well as ground before processing utilizing a Community Bureau of Reference (BCR) sequential extraction procedure. The fraction of the target metals in the extracted samples were then determined by flame atomic absorption spectroscopy (FAAS). The mobility factor (\%MF) of the target metals was investigated in both vertical and horizontal variations and the obtained results showed that the target metals have exhibited both vertical and horizontal mobility. The texture, organic matter and $\mathrm{pH}$ of the soil samples were also analyzed for correlation study. Variation among obtained results, i.e., \%MF and concentration of analytes, were evaluated using one way ANOVA at $(P \leq 0.05)$. It was observed that $C d$ and $\mathrm{Pb}$ exhibited vertical mobility and thus could lead to pollution of the underground water. Similarly, the highest amount of $\mathrm{Pb}$ in the bioavailable fraction may also indicate its horizontal mobility and its high tendency to pollute surface water, sediment as well as agricultural products.
\end{abstract}

Key Words: Speciation, Mobility, Sequential extraction, Heavy metals

\section{Introduction}

Soil is a reservoir of many heavy metals from both natural and anthropogenic sources (Abul, 2010). Metals exist in the soil in various forms and most of them have toxic effects on living organisms when exceeding certain concentration limits (Oluseyi et al., 2014). Dumpsite is one of the major causes of soil, underground and surface water as well as agricultural crops pollution by releasing toxic chemicals such as heavy metals (Oluseyi et al., 2014). Heavy metals can move in soil profile vertically or horizontally from the point where they are accumulated to other areas via different mechanisms. They may also affect the health of human 
beings; from simple poisoning to cancer, heart diseases and genetic abnormalities (Thomas, 2015; Jena et al., 2013).

The toxicity, environmental mobility and potential risk level of heavy metals are strongly dependent on their chemical speciation (Uduma and Jimoh, 2013). Speciation study involves identification and quantification of one or more individual chemical forms of the metals that occurs in a given sample. Such study provides sufficient information about the nature and the fraction of individual chemical species of metals in the soil. It also provides information about the affinity and strength with which metals are bound to the soil components (Fadiran et al., 2014; Zerbe et al., 1999).

The fractions of heavy metals in the soil profile, varies with the origin of the metals, availability, their forms of occurrence and mobility (Thomas, 2015). High fractionation of the total metals in the water soluble, exchangeable, bound to carbonates and reducible fractions is a good indication of anthropogenic pollution (Agbaire and Akporhonor, 2014). Similarly, the mobility of metals in the soil profile is also strongly dependent on their chemical forms (Sungur et al., 2014). It is usually determined based on the relative amount of the metal in water soluble, exchangeable as well as bound to carbonates fraction and their overall potential mobility is usually expressed as mobility factor (\% MF) (Wuana et al., 2012).
In general, several attempts were made to assess the mobility of heavy metals in contaminated soils and sediments using sequential extraction procedure so as to separate the mobile fraction which is responsible for environmental pollution (Sungur et al., 2014; Baruah et al., 2011). Even though, disposal of wastes at Kofe dumpsite has usesd for more than a couple of decades, no study has been conducted regarding the mobility of heavy metals in the dumpsite soils through speciation. Therefore, this study was aimed to assess the speciation and mobility of selected heavy metals including $\mathrm{Cd}, \mathrm{Pb}$ and $\mathrm{Fe}$ using a four steps BCR sequential extraction method (Ure et al., 1993) followed by FAAS.

\section{Materials and Methods Sample Sites}

Soil samples were collected from Kofe dumpsite of Jimma town, which is located in southwestern part of Ethiopia. The dumpsite is located at about $4 \mathrm{~km}$ in southwest of the town. Both solid and liquid municipal wastes from hotels, communities and higher learning institutions, like Jimma University and Jimma Teacher Training College have been discharged at the dumpsite for more than two decades. Figure 1, shows the map of Jimma zone, Jimma Town and Kofe dumpsite. 


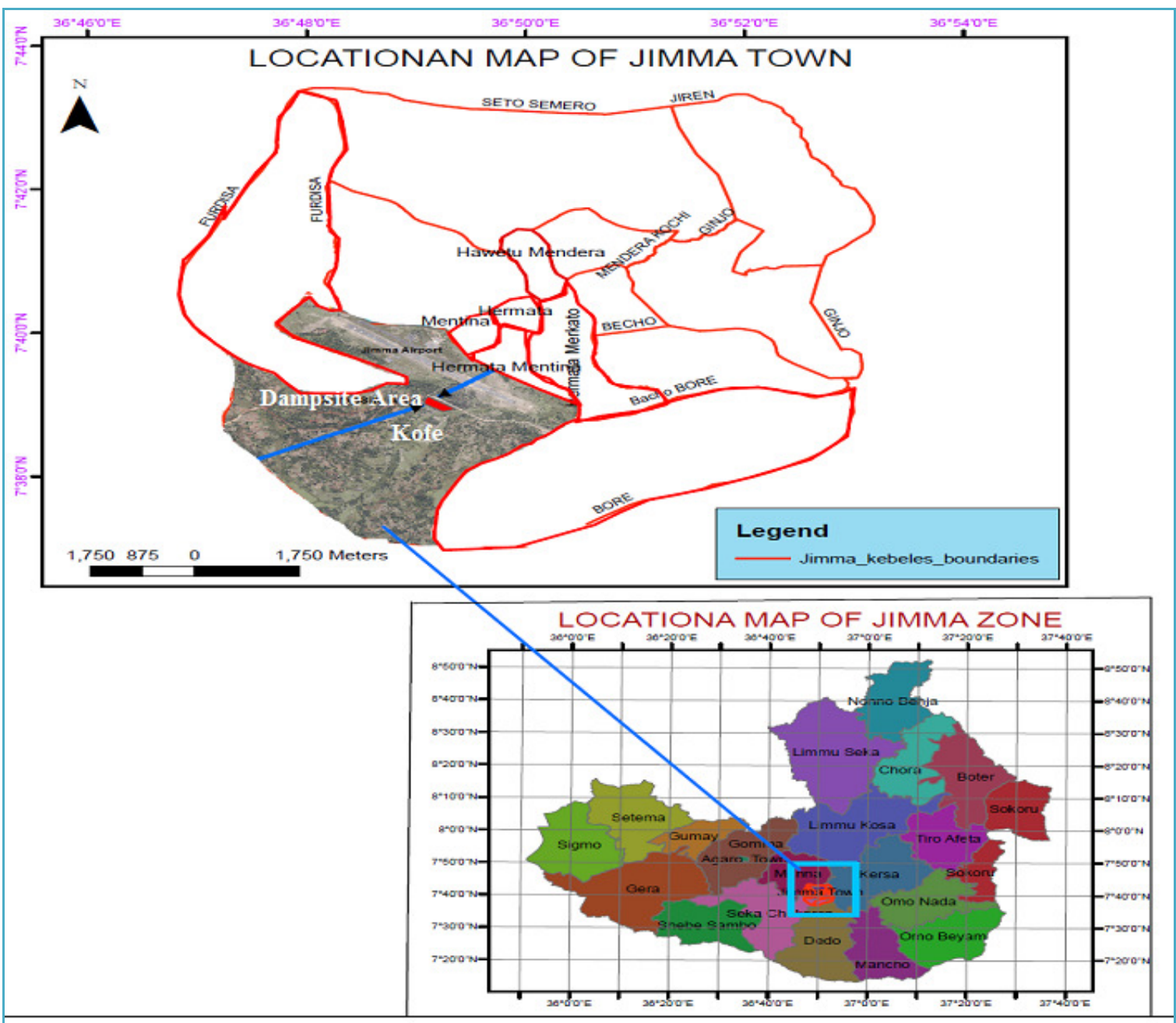

Figure 1: Sketch map of Jimma zone, Jimma town and Kofe dumpsite

\section{Sample Collection}

To study the vertical mobility of the metals, soil samples were collected from 12 randomly selected sites, at three depth profiles: surface soil $(0-10 \mathrm{~cm})$, subsoil $(20-30 \mathrm{~cm})$, bottom soil $(40-50 \mathrm{~cm})$ using soil auger. Similarly, for horizontal mobility study, the samples were collected at $5 \mathrm{~m}$ variations (i.e., at 5, 10, $15 \mathrm{~m})$, in east, west, north and south directions, starting from the edge of dumpsite. The control soil samples were also collected, at the same depth profiles, from about $200 \mathrm{~m}$ distance away from the dumpsite. Subsequently, the collected samples were homogenized according to their profiles at the sampling site and 1 $\mathrm{kg}$ composite samples were separately taken into polyethylene bags for each profile. Eventually, the samples were transported to laboratory, where they were oven dried at $105{ }^{\circ} \mathrm{C}$ prior to storing below $4{ }^{\circ} \mathrm{C}$.

\section{Sample Preparation Techniques}

The oven dried samples were further exposed to air and dried to constant weight. The impurities were removed by sieving with $2 \mathrm{~mm}$ pore size sieve. The samples were then divided into half, quartet and so on until the desired 
Speciation and Mobility Study of Selected Heavy Metals in Kofe...................ASSIM et al.

amounts of laboratory samples were taken. The samples were again oven dried at $105{ }^{\circ} \mathrm{C}$ and then, ground into fine sizes using mortar and pestle. Finally, the samples were stored in clean plastic bags and kept at room temperature until sample preparation step was carried out.

Physicochemical Properties of the Dumpsite Soil

Physicochemical properties including $\mathrm{pH}$, soil organic matter (\% OM) and soil texture were investigated. $\mathrm{pH}$ was determined using supernatant suspension of $1: 2.5$ soil water mixtures. \% OM was analyzed using wet oxidation method and after mechanical analysis of soil bulk density by standard procedure (Reeuvijik, 2002). Soil textural classification was investigated using chart method (Antoniadis, 1998).

\section{Sequential Extraction Procedures}

For speciation and mobility study of the target metals, a Community Bureau of Reference (BCR) sequential extraction procedure (Ure et al., 1993; Tokalioglu et al., 2000; Katana et al., 2013) was adopted. The procedure involves four fractionation steps: the water and acid soluble mobile fraction (F-I); reducible fraction (F-II); oxidizable fraction (F-III); and residual fraction (F-IV).

\section{Wet Digestion Procedure}

Baker and Amacher method was employed for wet digestion (Zeng et al., 2002).

Analytical Performance Study of Target Metals

For quantitative determinations, calibration curves were constructed by preparing series of solutions containing different concentrations of the target metal standards in $1 \mathrm{M} \mathrm{HNO}_{3}$. The calibration curves were obtained by plotting the measured absorbance versus concentration and demonstrated good linearity with coefficient of determinations $\left(\mathrm{r}^{2}\right)$ of $0.999,0.990$ and 0.994 for $\mathrm{Cd}, \mathrm{Pb}$ and $\mathrm{Fe}$, respectively.

Limit of detections (LODs) and limit of quantifications (LOQs) of the method were determined from the standard deviation of several blank determinations (Christian, 2004). Recovery studies were also performed in two ways: 1) using the method reported by (Uduma and Jimoh; 2013), which is determined as follows.

$(\% \mathrm{R})$ Sequential extraction $=\left(\frac{\mathrm{n} \sum \text { Fractions obtained by aequential procedureE }}{\text { wet digestion with strong acidz }}\right) \times 100$

2) by spiking known concentration of the target metal standards on to the sample and calculated as follows.

$(\% \mathrm{R})$ total analysis by spiking $=\frac{\text { Agpiked sample-non spiked sample }}{\text { Amount of metal spiked }} \times 100$

In addition, the mobility of the target metals was also evaluated in terms of mobility factor $\% \mathrm{MF}$ (Wuana et al., 2012), which is obtained as follows.

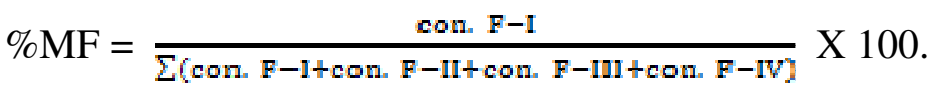




\section{Statistical Analysis}

One way ANOVA ( $\mathrm{p} \leq 0.05)$ was employed to evaluate the correlations of the concentrations as well as the mobility factors of the heavy metals fractions.

\section{Results and Discussion}

Physicochemical Prosperities of the Dumpsite Soil

Table 1: The physicochemical properties of the soil samples

\begin{tabular}{lllll}
\hline Sample & Profile & $\mathrm{pH}$ & $\% \mathrm{OM}$ & Soil texture \\
\hline Dump site & Upper & $5.80 \pm 0.06$ & $2.90 \pm 0.05$ & Silty Clay loamy \\
soil sample & Middle & $4.70 \pm 0.05$ & $3.80 \pm 0.02$ & Silty loam \\
& Bottom & $4.30 \pm 0.10$ & $3.87 \pm 0.02$ & Silty loam \\
\hline Horizontal & $5 \mathrm{~m}$ & $4.70 \pm 0.02$ & $3.23 \pm 0.10$ & Silty clay loam \\
soil sample & $10 \mathrm{~m}$ & $4.40 \pm 0.03$ & $3.90 \pm 0.02$ & clay loam \\
& $15 \mathrm{~m}$ & $4.10 \pm 0.07$ & $4.52 \pm 0.01$ & Clay \\
\hline Control & Upper & $4.60 \pm 0.02$ & $5.68 \pm 0.03$ & Clay \\
soil sample & Middle & $4.30 \pm 0.03$ & $4.60 \pm 0.01$ & Clay \\
& Bottom & $4.00 \pm 0.01$ & $3.42 \pm 0.02$ & Clay \\
\hline
\end{tabular}

It was observed that $\mathrm{pH}$ of soil samples were varied from 5.80-4.30; 4.60-4.00 and 4.70-4.10 for dumpsite, control and horizontal soil samples, respectively. In all cases, $\mathrm{pH}$ values were in acidic range (i.e., < 7.00), and their acidity increases vertically as well as horizontally and thus facilitating desorption of the metals from the soil (Ogbemudia and Mbong, 2013). The finding also demonstrated control soil sample has larger \%OM than the dumpsite soil samples. Such variation could be attributed to the difference in the level of decomposable plant and waste matter of the soils (Richards et al., 2000; Matos et al., 2000). In contrast to the control soil samples, \%OM in dumpsite soil samples exhibited an increment with depth in vertical profiles. This could be related to the availability of nondecomposable materials such as plastics, rubbers and other materials at the surface of the dumpsite soils (Lawan et al., 2012). The texture of dumpsite soil samples were also varied from the control sample, which were completely clay type, whereas, dumpsite soils have silty clay loam and clay loam textures, which could facilitate the percolation of heavy metals and other colloids to the lower profile (Soriano-Disla et al., 2011).

\section{Limits of Detection Quantification}

LODs and LOQs of the method were determined for each fraction (Table 2). It was observed that $\mathrm{Cd}$ and $\mathrm{Fe}$ exhibited different LODs and LOQs in F-I, but same values in other fractions. In the study, metal concentrations obtained below LOD as well as between LOD and LOQ, at the particular fraction were reported as not detected (ND) and detected not quantifiable (DNQ), respectively. 
Table 2: LODs and LOQs of the target metals in $\mu \mathrm{g} / \mathrm{g}$

\begin{tabular}{lllllll}
\hline & Cd & & Pb & & Fe & \\
Fraction & LOD & LOQ & LOD & LOQ & LOD & LOQ \\
\hline F-I & 0.02 & 0.07 & 0.01 & 0.03 & 0.07 & 0.23 \\
F-II & 0.01 & 0.03 & 0.01 & 0.03 & 0.05 & 0.17 \\
F-III & 0.01 & 0.03 & 0.01 & 0.03 & 0.05 & 0.17 \\
F-IV & 0.01 & 0.03 & 0.01 & 0.03 & 0.05 & 0.17 \\
\hline
\end{tabular}

\section{Speciation and Vertical Mobility of Selected Heavy Metals in the Dumpsite Soils}

The concentrations of the target metals in different fractions are presented in Table 3.

Table 3: Concentrations of the metals by fractions in the vertical profiles (Mean $\pm \mathrm{SD}, \mathrm{n}=6$ )

\begin{tabular}{|c|c|c|c|c|c|c|c|}
\hline \multirow{2}{*}{ Profile } & \multirow{2}{*}{ Fraction } & \multicolumn{3}{|c|}{ Dumpsite soil $(\mu \mathrm{g} / \mathrm{g})$} & \multicolumn{3}{|c|}{ Control soil $(\mu \mathrm{g} / \mathrm{g})$} \\
\hline & & $\mathrm{Cd}$ & $\mathrm{Pb}$ & $\mathrm{Fe}$ & $\mathrm{Cd}$ & $\mathrm{Pb}$ & $\mathrm{Fe}$ \\
\hline \multirow{5}{*}{ Upper } & F-I & $0.56 \pm 0.01$ & $5.00 \pm 0.01$ & $5.00 \pm 0.04$ & ND & ND & $6.00 \pm 0.02$ \\
\hline & F-II & $2.43 \pm 0.02$ & $5.10 \pm 0.01$ & $4.20 \pm 0.02$ & ND & ND & $24.00 \pm 0.03$ \\
\hline & F-III & $1.32 \pm 0.03$ & $4.40 \pm 0.02$ & $7.30 \pm 0.14$ & ND & ND & $3.20 \pm 0.04$ \\
\hline & F-IV & $0.22 \pm 0.03$ & $1.20 \pm 0.04$ & $3.50 \pm 0.40$ & ND & ND & ND \\
\hline & SF & $4.34 \pm 0.09$ & $15.70 \pm 0.08$ & $20.00 \pm 1.50$ & - & - & $33.20 \pm 0.09$ \\
\hline \multirow{5}{*}{ Middle } & F-I & $0.85 \pm 0.02$ & $9.00 \pm 0.05$ & $8.10 \pm 0.21$ & ND & DNQ & $5.00 \pm 0.05$ \\
\hline & F-II & $1.35 \pm 0.03$ & $5.50 \pm 0.03$ & $9.50 \pm 0.04$ & DNQ & DNQ & $10.00 \pm 0.03$ \\
\hline & F-III & $0.51 \pm 0.05$ & $5.50 \pm 0.14$ & $5.40 \pm 0.06$ & DNQ & ND & $12.00 \pm 0.02$ \\
\hline & F-IV & $0.87 \pm 0.10$ & $1.50 \pm 0.05$ & $1.50 \pm 0.05$ & ND & ND & $1.50 \pm 0.03$ \\
\hline & SF & $2.57 \pm 0.20$ & $20.50 \pm 0.27$ & $24.50 \pm 0.36$ & DNQ & DNQ & $28.50 \pm 0.13$ \\
\hline \multirow{5}{*}{ Bottom } & F-I & $0.52 \pm 0.30$ & $9.50 \pm 0.22$ & $5.20 \pm 0.02$ & ND & ND & $1.50 \pm 0.12$ \\
\hline & F-II & $0.68 \pm 0.20$ & $3.20 \pm 0.04$ & $13.30 \pm 0.03$ & ND & ND & $7.30 \pm 0.08$ \\
\hline & F-III & ND & $5.00 \pm 0.02$ & $3.50 \pm 0.03$ & ND & ND & $8.00 \pm 0.40$ \\
\hline & F-IV & ND & $0.70 \pm 0.04$ & ND & ND & ND & $9.00 \pm 0.06$ \\
\hline & SF & $1.20 \pm 0.50$ & $18.40 \pm 0.12$ & $22.50 \pm 0.08$ & - & - & $25.80 \pm 0.66$ \\
\hline
\end{tabular}

ND: Not detected; DNQ: Detected not quantifiable; F-I: Mobile fraction; F-II: Reducible fraction;

F-III: Oxidizable fraction; F-IV: Residual fraction; SF: Sum of fractions

It was observed that concentrations of the metals in F-I were varied in vertical profiles ranging from $0.52-0.56,5.00-$ 9.50 and $5.00-5.20 \mu \mathrm{g} / \mathrm{g}$ for $\mathrm{Cd}, \mathrm{Pb}$ and Fe, respectively. Specifically, the concentration of $\mathrm{Pb}$ in F-I increases down the vertical profile. The ANOVA test ( $\mathrm{p}$ $\leq 0.05$ ) also demonstrated the existence of significant difference in $\mathrm{Cd}, \mathrm{Pb}$ and $\mathrm{Fe}$ concentrations in vertical soil profiles, indicating the high mobility of $\mathrm{Pb}$ and $\mathrm{Cd}$ towards the pollution of underground water (Sherene, 2010; Kanmani and
Gandhimathi, 2013). In all fractions of the control soil samples, $\mathrm{Pb}$ and $\mathrm{Cd}$ were not detected and/or detected below the LOQ, demonstrating the absence of the natural sources of these metals in the control site soils (Tripathi and Misra, 2012). The bioavailable fraction of $\mathrm{Fe}$ in the control soil has not exhibited significant difference down the soil profile which might be due to the clay nature of soil and high \% OM in the upper profile (Lawan et al., 2012; Violante et al., 2010). 
It was also observed that in the different fractions of the dumpsite and control soil samples, the studied heavy metals have exhibited variations. Earlier reports also confirmed the possibility of variations of heavy metals in different fractions of the soil (Zerbe, 1999). Compared to the control soil samples, $\mathrm{Pb}$ and $\mathrm{Cd}$ were found in higher concentrations in all profiles of the dumpsite soils, indicating the suitable conditions for their existence in the mobile fractions of the dumpsite soils (Jena et. al., 2013; Kanmani and Gandhimathi, 2013). In suitable conditions oxidizable and reducible fractions of $\mathrm{Cd}$ and $\mathrm{Pb}$ could be easily converted to the bioavailable/mobile fraction (Antoniadis, 1998). The dumpsite and its surrounding area soil samples have also exhibited higher total concentrations of the studied metals. This could be attributed to the enrichments of the dumpsite soils with the studied metals resulting from uncontrolled solid and liquid municipal as well as commercial wastes dumped on the area (Mohammad and Kenneth, 2012; Bronius and Vaida, 2009).

\section{Vertical Mobility of Target Heavy} Metals in the Dumpsite Soil

Vertical mobility study provides important information about the level of toxicity or bioavailability the metals in the environment. Figure 2, shows vertical mobility of target metals in the dumpsite soils.

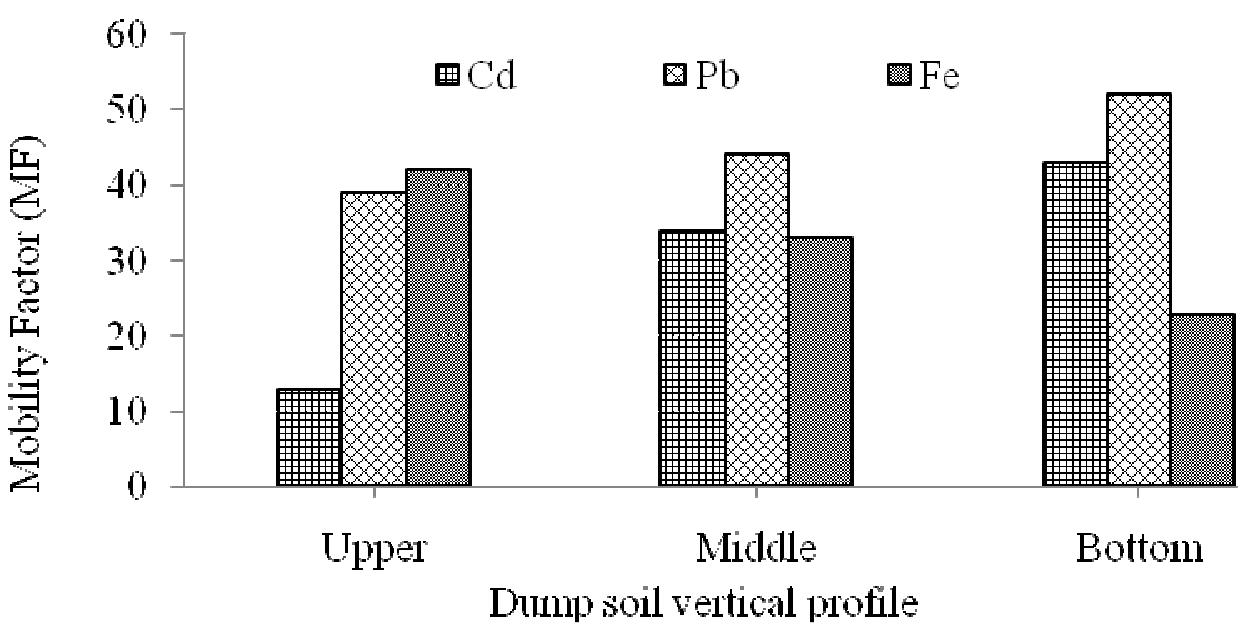

Figure 2: Vertical mobility factors of target metals in the Kofe dumpsite soils.

As indicated in Figure 2, mobility of $\mathrm{Pb}$ and $\mathrm{Cd}$ increase down the vertical soil profile. Therefore, the bottom dumpsite soil contains higher mobile fractions of toxic heavy metals, whose fate might be resulted in pollution of the surrounding underground water (Sherene, 2010; Kanmani and Gandhimathi, 2013).
However, Fe mobility decreases down the vertical profiles, indicating the presence of the majority of its mobile fraction at the upper surface.

In general, mobility of the metals down the dumpsite soil profiles follows the trend: $\mathrm{Pb}>\mathrm{Cd}>\mathrm{Fe}$. The ANOVA test $(p \leq 0.05)$ also confirmed the presence of 
significant variation of the metals down the soil profile. Similarly, the mobile fractions at each profile follow various trends, i.e., in upper $\mathrm{Fe}>\mathrm{Pb}>\mathrm{Cd}$; middle $\mathrm{Pb}>\mathrm{Fe} \approx \mathrm{Cd}$; and bottom $\mathrm{Pb}>$ $\mathrm{Cd}>\mathrm{Fe}$. In all cases, the highest mobile fraction was observed for $\mathrm{Pb}$, indicating a serious environmental concern of dumpsite soils.

\section{Speciation and Horizontal Mobility of Target Heavy Metals}

Speciation and horizontal mobility study can provide information about how far the mobile fractions of toxic metals and/or plant nutrients could migrate in soil surface from their point source to the surrounding areas. The concentrations of the studied metals in the horizontal soil profiles are presented in Table 4 .

Table 4: Concentration of target metals in horizontal soil samples

\begin{tabular}{lllll}
\hline \multirow{2}{*}{ Profile } & Fraction & \multicolumn{2}{l}{ Concentration $(\mu \mathrm{g} / \mathrm{g})$} & \\
& & $\mathrm{Cd}$ & $\mathrm{Pb}$ & $\mathrm{Fe}$ \\
\hline \multirow{2}{*}{$5 \mathrm{~m}$} & F-I & $0.25 \pm 0.02$ & $7.80 \pm 7.80$ & $9.20 \pm 0.04$ \\
& F-II & $0.62 \pm 0.10$ & $5.20 \pm 0.04$ & $10.40 \pm 0.07$ \\
& F-III & $0.79 \pm 0.03$ & $5.20 \pm 0.04$ & $2.10 \pm 0.30$ \\
& F-IV & ND & $0.78 \pm 0.05$ & ND \\
& SF & $1.66 \pm 0.15$ & $18.98 \pm 0.15$ & $21.70 \pm 0.41$ \\
\hline & F-I & $0.65 \pm 0.10$ & $12.70 \pm 0.05$ & $9.80 \pm 0.05$ \\
$10 \mathrm{~m}$ & F-II & $0.64 \pm 0.10$ & $4.20 \pm 0.30$ & $10.20 \pm 0.30$ \\
& F-III & $0.45 \pm 0.10$ & $5.00 \pm 0.20$ & $5.00 \pm 0.23$ \\
& F-IV & $0.26 \pm 0.12$ & ND & ND \\
& SF & $2.00 \pm 0.42$ & $21.90 \pm 0.55$ & $25.00 \pm 0.58$ \\
\hline & F-I & $0.82 \pm 0.02$ & $28.80 \pm 0.04$ & $10.00 \pm 0.03$ \\
& F-II & $0.24 \pm 0.10$ & $4.00 \pm 0.10$ & $15.30 \pm 0.50$ \\
& F-III & $0.44 \pm 0.15$ & $1.20 \pm 0.02$ & ND \\
& F-IV & ND & $2.50 \pm 0.05$ & ND \\
& SF & $1.50 \pm 0.27$ & $36.50 \pm 0.21$ & $25.30 \pm 0.53$ \\
\hline
\end{tabular}

The findings indicated that the target metals were shown different concentrations of mobile fractions ranging from $0.25-0.82 \mu \mathrm{g} / \mathrm{g}, 7.8-28.8$ $\mu \mathrm{g} / \mathrm{g}$ and $9.2-10.00 \mu \mathrm{g} / \mathrm{g}$ for $\mathrm{Cd}, \mathrm{Pb}$ and $\mathrm{Fe}$, respectively, as the distance increases from the dumpsite. The increase in the concentration of $\mathrm{Cd}$ and $\mathrm{Pb}$ in mobile fraction might be attributed to the acidity and higher \% OM of the soil, which facilitate migration of the metals in the mobile fraction, as has been also indicated in the literature (Ashworth and Alloway, 2008). The total concentrations of Fe also increase with distance up to 10 $\mathrm{m}$ away from the dumpsite and then, become constant for longer distances. However, its bioavailable fraction has not shown significant variation, may be due to the preference of $\mathrm{Fe}$ to bound in reducible fraction (Tokalioglu et al., 2000). 
Horizontal Mobility of the Target Heavy Metals

As has been mentioned earlier, mobility is described in terms of $\% \mathrm{MF}$
(Ashworth and Alloway, 2008). Figure 3, illustrates horizontal mobility of the studied metals.

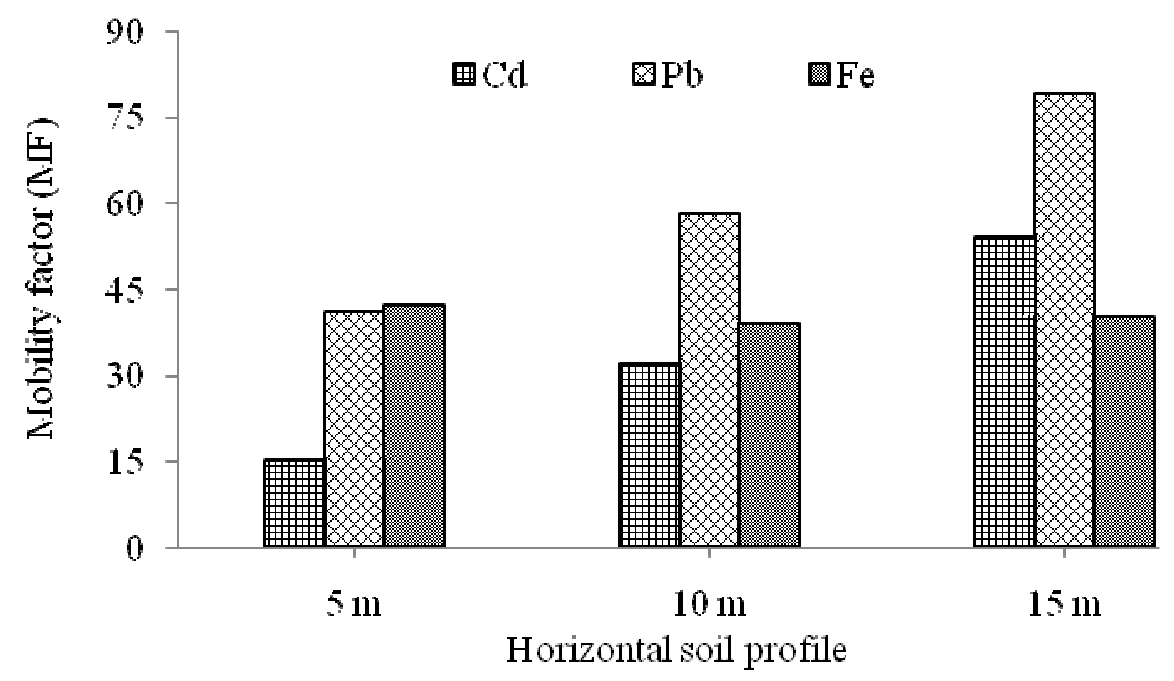

Figure 3: Horizontal mobility factor of the target metals.

The finding demonstrated linear increment in the mobility of $\mathrm{Pb}$ and $\mathrm{Cd}$ with distance from the dumpsite. This could be happened due to the increased in the acidity and the \% OM of the soils as one goes away from the dumpsite (Ogbemudia and Mbong, 2013; Richards et al., 2000). The AOVA test (at $\mathrm{p} \leq$ 0.05 ) also revealed the existence of significance differences in $\mathrm{Cd}$ and $\mathrm{Pb}$ mobile fractions along horizontal profiles. The trend of their horizontal mobility shows the possibility of contamination of the soil, sediment, surface water and agricultural products in nearby areas as dumping is continued for longer time (Mohammad and Kenneth, 2012; Wuana et al., 2012; Bronius and Vaida, 2009).

Recovery Study of the Target Heavy Metals

The results of recovery studies for both sequential extraction and total analysis are presented in Table 5. 
Table 5: Speciation recovery and wet digestion recovery of the target metals

\begin{tabular}{|c|c|c|c|c|c|c|c|c|c|c|c|c|c|c|c|c|c|c|c|c|c|c|c|c|c|c|c|}
\hline \multirow{3}{*}{$\begin{array}{l}\text { Sample } \\
\text { type } \\
\text { Profile } \\
\text { Analyte }\end{array}$} & \multicolumn{9}{|c|}{ Dumpsite Soil (vertical) samples } & \multicolumn{9}{|c|}{ Horizontal soil sample } & \multicolumn{9}{|c|}{ Control soil sample } \\
\hline & \multicolumn{2}{|c|}{ Upper } & \multicolumn{4}{|c|}{ Middle } & \multicolumn{3}{|c|}{ Bottom } & \multicolumn{2}{|c|}{$5 \mathrm{~m}$} & \multicolumn{3}{|c|}{$10 \mathrm{~m}$} & \multicolumn{3}{|c|}{$15 \mathrm{~m}$} & \multicolumn{3}{|c|}{ Upper } & \multicolumn{3}{|c|}{ Middle } & \multicolumn{4}{|c|}{ Bottom } \\
\hline & $\mathrm{Cd}$ & $\mathrm{Pb}$ & $\mathrm{Fe}$ & $\mathrm{Cd}$ & $\mathrm{Pb}$ & $\mathrm{Fe}$ & $\mathrm{Cd}$ & $\mathrm{Pb}$ & $\mathrm{Fe}$ & $\mathrm{Cd}$ & $\mathrm{Pb}$ & $\mathrm{Fe}$ & $\mathrm{Cd}$ & $\mathrm{Pb}$ & $\mathrm{Fe}$ & $\mathrm{Cd}$ & $\mathrm{Pb}$ & $\mathrm{Fe}$ & $\mathrm{Cd}$ & $\mathrm{Pb}$ & $\mathrm{Fe}$ & $\mathrm{Cd}$ & $\mathrm{Pb}$ & $\mathrm{Fe}$ & $\mathrm{Cd}$ & $\mathrm{Pb}$ & $\mathrm{Fe}$ \\
\hline$\% \mathrm{R}$ & 93 & 90 & 69 & 71 & 106 & 97 & 77 & 108 & 87 & 87 & 97 & 99 & 84 & 100 & 104 & 80 & 99 & 92 & - & - & 98 & 115 & 81 & 111 & - & - & 86 \\
\hline$\% \mathrm{RS}$ & 80 & 84 & 92 & 80 & 106 & 92 & 89 & 92 & 106 & 94 & 90 & 94 & 80 & 90 & 102 & 88 & 92 & 90 & 99 & 100 & 106 & 104 & 87 & 92 & 100 & 100 & 96 \\
\hline
\end{tabular}


The recovery values of the target metals, by both methods: sequential extraction procedure and spiked acid digested samples were ranging from 69$115 \%$ and $80-106 \%$, respectively, indicating acceptable recoveries. Comparison of the two recovery studies indicates that the total amounts of analytes obtained by summation of the individual fractions in the speciation analysis and total analysis by wet digestion procedure are almost the same.

\section{Conclusion}

In this study, speciation and mobility of heavy metals including $\mathrm{Cd}, \mathrm{Pb}$ and $\mathrm{Fe}$ in Kofe dumpsite were investigated. The findings demonstrated that the studied metals exist in the dumpsite soils in different form and also exhibited vertical and horizontal mobility. As compared to the control soil sample, the dumpsite contain higher amount of $\mathrm{Cd}$, and $\mathrm{Pb}$, attributing to anthropogenic sources resulting from the availability of solid and liquid wastes at the dumpsite. The variation in the physicochemical properties of soils such as $\mathrm{pH}, \% \mathrm{OM}$ and texture might be the cause for the variations of concentrations of bioavailable fractions of the metals in the dumpsite soil. $\mathrm{Cd}$ and $\mathrm{Pb}$ exhibited both horizontal and vertical mobility and thus, they pollute the nearby surface water, sediments and agriculture crops. Similarly, larger concentration of Fe was observed in reducible fraction in the dumpsite and oxidizable fraction in the control soils, indicating its low bioavailability relative to $\mathrm{Cd}$ and $\mathrm{Pb}$. The findings of the study demonstrated that the studied dumpsite soil is not suitable or safe for agricultural purposes.

\section{Acknowledgments}

Financial support for some of the work was obtained from school of graduate studies of Jimma University.

\section{References}

Agbaire, P.O. and Akporhonor, E.E. (2014). Heavy metal determination by sequential extraction in agricultural farmland soils in selected farms in Abraka, Delta State, Nigeria. Journal of Environmental Science, Toxicology and Food Technology, 8(6): 47-55.

Antoniadis, V. (1998). Heavy metal availability and mobility in sewage sludge treated soil. Ph.D Thesis, submitted to university of Reading, department of soil science, pp1564.

Ashworth, D.J. and Alloway, B.J. (2008). Influence of dissolved organic matter on the solubility of heavy metals in sewage-sludge-amended soils, Soil and Sediment Contamination, 39(3-4): 538-550.

Baruah, B.K., Das, B., Haque, A., Medhi, C. and Misra, A.K. (2011.) Sequential extraction of common metals ( $\mathrm{Na}, \mathrm{K}, \mathrm{Ca}$ and $\mathrm{Mg}$ ) from surface soil from surface soil, Journal of Chemical and Pharmaceutical Research, 3(5): 565-573.

Bronius, J. and Vaida, L. (2009). Investigation of influence of lapse landfill leachate on ground and surface water pollution with heavy metals, Journal of Environmental Engineering and Landscape Management, 17(3): 131-139.

Christian G.D. (2004) Analytical chemistry, $2^{\text {nd }}$ ed., John Wiley and Sons, Inc: USA, pp111-112. 
Fadiran, A.O., Tiruneh, A.T. and Mtshali, J.S. (2014). Assessment of mobility and bioavailability of heavy metals in sewage sludge from Swaziland through speciation analysis, American Journal of Environmental Protection, 3(4): 198-208.

Jena, V., Gupta, S., Dhundhel, R.S., Matic, N., Bilinski, S.F. and Devic, N. (2013). Determination of total heavy metal by sequential extraction from soil, International Journal of Research in Environmental Science and Technology, 3(1): 35-38.

Kanmani, S. and Gandhimathi, R. (2013). Assessment of heavy metal contamination in soil due to leachate migration from an open dumping sit., Applied Water Science, 3(1): 93-205.

Katana, C., Jane, M. and Harun, M. (2013). Speciation of chromium and Nickel in open-air automobile mechanic workshop soils in Ngara, Nairobi, Kenya, World Environment, 3(5): 143154.

Lawan, I. B., Stephen, S. H., Goni, A.D and Muhammad, T. (2012) Study of vertical migration of heavy metals in dumpsites soil. ARPN Journal of Science and Technology, 2(2): 5055.

Matos, A. T., Fontes, M. P. F., Costa L. M., Martinez, M. A. (2000) Mobility of heavy metals as related to soil chemical and mineralogical characteristics of Brazilian soils. Environmental Pollution, 111(3): 429-435.

Mohammad, A. and Kenneth, M. (2012). Environmental impact of municipal solid waste landfills in semi-arid climates - case study-Jordan, The
Open Waste Management Journal, 5(1): 28-39.

Ogbemudia, F.O. and Mbong, E.O. (2013). Soil reaction $(\mathrm{pH})$ and heavy metal index of dumpsites within Uyo municipality. Merit Research Journal of Environmental Science and Toxicology, 1(4): 082085.

Oluseyi, T., Adetunde, O. and Amadi, E. (2014). Impact assessment of dumpsite on quality of nearby soil and underground water. A case study of functional dumpsite in Lagos, Nigeria, International Journal of Environmental Science and Technology, 3(3): 1004-1015.

Reeuvijik, L.P. (2002). International soil reference Information center, food and agriculture of organization, United Nations, Netherlands, 1-6.

Richards, B.K., Steenhuis, T. S., Peverly, J.H. and Mcbride M.B. (2000). Effect of sludge-processing mode, soil texture and soil $\mathrm{pH}$ on metal mobility in undisturbed soil columns under accelerated loading. Environmental Pollution, 109: 327346.

Sherene, T. (2010). Mobility and transport of heavy metals in polluted soil environment. Biological Forum of International Journal, 2(2): 112-121.

Soriano-Disla, J.M., Gomez, I. and Navarro-Pedreño, J. (2011). The influence of soil properties on the mobility of metals following a single application of polluted sewage sludge to seventy agricultural top soil, Soil and Sediment Contamination, 20(8): 961-976. 
Sungur, A., Soylak, M. and Ozcan, H. (2014). Investigation of heavy metal mobility and availability by the BCR sequential extraction procedure: relationship between soil properties and heavy metals availability. Chemical Speciation and Bioavailability, 26(4): 219-230.

Thomas, E.Y. (2015). Assessment of heavy metal concentration and fractionation in selected dumpsite soils within Ibadan metropolis, Nigeria. Journal of Agriculture and Ecology Research International 4(3): 117-127.

Tokalioglu, S., Karta, S. and Elçi, L. (2000). Determination of heavy metals and their speciation in lake sediments by flame atomic absorption spectrometry after a four-stage sequential extraction procedure, Analytica Chimica Acta, 413(1-2): 33-40.

Tripathi, A. and Misra, D.R. (2012). A study of physico-chemical properties and heavy metals in contaminated soils of municipal waste dumpsites at Allahabad, India, International Journal of Environmental Sciences, 2(4): 2023-2035.

Uduma, A.U. and Jimoh, W.L.O. (2013). Sequential extraction procedure for partitioning of Lead, Copper, Cadmium, Chromium and Zinc in contaminated arable soils of Nigeria. American Journal of Environment, Energy and Power Research, 1(9): 186-208.
Ure, A. M., Quevauviller, P., Muntau, H. and Griepink, B. (1993). Speciation of heavy metal in soils and sediments. An account of the improvement and harmonization of extraction techniques undertaken under the auspices of the BCR of the Commission of the European Communities. International Journal of Environmental Analytical Chemistry, 51(4): 135-151.

Violante, A., Cozzolino, V., Perelomov, L., Caporale, A. G. and Pigna, M. (2010). Mobility and bioavailability of heavy metal and metalloids in soil environments. Journal of Soil Science and Plant Nutrition, 10(3): 268-292.

Wuana, R.A., Adie, P.A., Asegh, I. N. (2012) Seasonal variation in bioavailability of some toxic metals in waste dump soils of Makurdi, North-Central Nigeria. Journal of Biodiversity and Environmental Science, 2(11): 7-17.

Zeng, Y.H., Zueng, S.C., Chen, C.T., Chun, C.T., Shuang, C., Chyan, L.I and Haw, T.L. (2002). Digestion methods for total heavy metals in sediments and soils. Water Air and Soil Pollution, 141(1): 189-205.

Zerbe, J., Sobczyński, T., Elbanowska, H. and Siepak, J. (1999). Speciation of heavy metals in bottom sediments of lakes, Polish Journal of Environmental Studies, 8(5): 331-339. 